\title{
Book:
}

The Geology of Iberia: A Geodynamic Approach

Quesada, C. \& Oliveira, J.T. - Springer, 2019

Volume 2 - Variscan Cycle

Capítulo 2

\section{The Cambrian-Early Ordovician Rift Stage in the Gondwanan Units of the Iberian Massif}

Teresa Sanchez-Garcia et al.

DOI: 10.1007/978-3-030-10519-8_2

\begin{abstract}
:
A rifting stage initiated the Variscan cycle in NW Gondwana, lasted from Terreneuvian to Early Ordovician times and culminated in opening of the Rheic Ocean. The result of lithospheric stretching was the development of a horst-and-graben structure in the upper crust and formation of basins with sharp variations in thickness and facies of the sedimentary infill. Emplacement of large volumes of igneous rocks, both plutonic and volcanic, accompanied this stage in three different intervals: (i) Early Igneous Event (Terreneuvian), exclusively composed of felsic peraluminous rocks associated with the formation of core complexes in the mid-upper crust; (ii) Main Igneous Event (Cambrian Series 2 to Furongian), displaying bimodal character; and iii) Late Event (TremadocianFloian), with mixed characteristics of the other two events and abundant peralkaline rocks. The rifting axis was initially located close to the Cadomian suture that fringed the Ossa Morena Zone. For about 60 m.y. the rifting processes initially propagated "ziplike" along the axis and then widened cratonward to affect inner parts of Gondwana, such as the Central Iberian Zone. The rift/drift transition was diachronous, starting in Iberia (Ossa Morena Zone) in the Furongian.
\end{abstract}

\section{Citation:}

Sanchez-Garcia, T., Chichorro, M., Solá, R., Alvaro, J.-J., Diez-Montes, A., Bellido, F., Ribeiro, M.L., Quesada, C., Lopes, J.C., Silva, I.F.D., Clavijo, E.G., Barreiro, J.G., López-Carmona, A. (2019) - The Cambrian-Early Ordovician Rift Stage in the Gondwanan Units of the Iberian Massif. In: Quesada C., Oliveira J. (eds) The Geology of Iberia: A Geodynamic Approach. Regional Geology Reviews. Springer, Cham, Vol. 2, The Variscan Cycle, Cap. 2, pp 27-74.

ISBN 978-3-030-10518-1; DOI: 10.1007/978-3-030-10519-8_2 